\title{
Behavior study of the doped castor bean polymer rod with bioactive glass and hidroxyapatite in mice femur medullary canal ${ }^{1}$
}

Viviani Teixeira dos Santos', Gilberto Gonçalves Facco", Hudman Cunha Ortiz"I', Iandara Schettert da Silvalv

'Fellow Master degree, Postgraduate Program in Health and Development, West Central Region, Universidade Federal de Mato Grosso do Sul (UFMS), Campo Grande-MS, Brazil. Intellectual and scientific content of the study, manuscript preparation.

"PhD, Full Professor, Universidade Anhanguera-Uniderp, Campo Grande-MS, Brazil. Histopathological examinations.

I'IFellow Master degree, Postgraduate Program in Health and Development, West Central Region, UFMS, Campo GrandeMS, Brazil. Critical revision.

IVPhD, Associate Professor, Postgraduate Program in Health and Development, West Central Region, UFMS, Campo GrandeMS, Brazil. Final approval.

\section{Abstract}

Purpose: To evaluate the polymer doped rods behavior with bioactive glass and hydroxyapatite for possible application as a fracture fixing method.

Methods: Twenty eight Rattus norvegicus Wistar underwent bone defect for access to the femoral medullary canal and distributed into three experimental groups: group A-doped castor bean polymer with bioactive glass; group B-castor bean polymer and; group C-castor bean polymer doped with bioactive glass and hydroxyapatite. After 15 and 60 evaluation days, the femurs were removed and sent for histology and scanning electron microscopy.

Results: Initially mild and moderate inflammatory infiltrate is observed that decreases as time goes by, and the presence of connective tissue capsule around the graft in all groups. Regarding the biomaterials resorption little was observed. The implanted rods did not favor the osteoconductive process in the femoral medullary canal which was observed only in the C15 group.

Conclusion: The association of castor bean polymer, bioactive glass and hydroxyapatite was biocompatible and osteointegrable. The osteoconductive only occurred in the presence of hydroxyapatite and bioactive glass (C15 Group) and little biodegradation was observed.

Key words: Castor Bean. Polyurethanes. Durapatite. Biocompatible Materials. Rats. 


\section{- Introduction}

Intramedullary rods made of stainless steel or titanium have been widely used in the long bone fractures immobilization. However, there are many records of complications related to their use ${ }^{1}$.

The technological advance has allowed the development of a great variety of material instruments for implant and techniques for the internal fixation of fractures in humans. In this way, the search for lighter, more resistant, low cost and biocompatible materials has grown ${ }^{2}$ for more biological solutions and replacing artifacts such as wire rods and metal plates by bioreabsorbable polymers in the fractures treatment ${ }^{3}$.

Among these polymers, polyurethane derived from castor oil has been outstanding because it is a low cost material developed in Brazil that has excellent structural properties, which has been shown to be biocompatible ${ }^{4}$, and for combining the versatility of the polymer formulation while addressing the global concern in the production of new biomaterial resources becoming one of the most studied $^{5}$.

Bioactive glasses have unique binding properties to the bone surface, their main characteristic being the ability to promote chemical bonding with hydroxyapatite and to act as a framework for bone growth ${ }^{6}$. The potentials of bone neoformation and mechanical resistance of bioactive glass were tested in several animals and in vitro studies, proving the promising potential as a bone substitute, because it is biocompatible, with bioactive and osteoconductive properties ${ }^{7}$.

Hydroxyapatite is widely used to fill bone defect because it is biocompatible, reabsorbable and osteoconductive, that is, it serves as a framework for the migration of osteoprogenitor cells ${ }^{8}$. However, hydroxyapatite presents low mechanical resistance and high fragility, which makes its use restricted. One way to improve this property is to associate it with other materials such as bioactive glass ${ }^{7}$.

Thus, the aim of this study is to analyze the behavior of doped castor bean oil polymer rods with bioactive glass and hydroxyapatite in the femur medullary canal in mice to a possible application as a method for fractures fixation and bone repair.

\section{Methods}

All experimental procedures were approved by the Ethics Committee on Animal Use (CEUA) from Universidade Federal do Mato Grosso do Sul (UFMS) as protocol n\# 270/2010.

Twenty eight Rattus norvegicus were used, in albino Wistar lineage, with body weight ranging from 250 to $300 \mathrm{~g}$. These animals were randomly divided into three groups according to the biomaterial used, Group A - implant composed of castor bean polymer doped with bioactive glass; Group B - implant composed of castor bean polymer and; Group C - implant consisting of castor bean polymer doped with bioactive glass and hydroxyapatite. Each group was divided into two subgroups according to the euthanasia period, at 15 and 60 days being namely: A15 and A60 Group and C15 and C60 Group composed of 05 animals in each group and B15 and B60 composed of 04 animals each.

Intramedullary rods were prepared with three different compositions from the group. Group A castor bean polymer with concentration of $12 \%$ calcium carbonate and doped with $12 \%$ of bioactive glass; Group $B$ castor bean polymer with concentration of $54 \%$ calcium carbonate (according to manufacturer's instructions) and Group $C$ castor bean polymer with concentration of $8 \%$ calcium carbonate and doped with $8 \%$ of 
bioactive glass and $8 \%$ hydroxyapatite.

After performing several pilot tests, the powder fraction (calcium carbonate, hydroxyapatite and castor bean polymer) used in group $A$ and group C was determined in $24 \%$. This amount, as well as the need of bioactive glass group containing hydroxyapatite group, was the maximum possible to be employed so that the material reached the manipulable state and maintained the desired mechanical properties.

The rods with approximately $0.7 \mathrm{~mm}$ in diameter and $2 \mathrm{~cm}$ in length were made by extrusion using $3 \mathrm{ml}$ syringes and $40 \times 1,2$ needles. These implants remained standing for about 48 hours on a polyethylene plate for complete polymerization. Then, these rods were individually sterilized by ethylene oxide to be used in the operative procedure. Initially, the animals were anesthetized with intraperitoneal injection of Zoletil in doses of $0.1 \mathrm{ml} / 100 \mathrm{~g}$ of body weight. Then, in the cortical bone, the femoral diaphysis drilling was carried out until the medullary canal using a drill of 0.7 $\mathrm{mm}$ of diameter attached to an odontology back angle activated by low speed engine implant under constant saline irrigation. From this bone defect carried out in cortical bone an intramedullary rod was introduced. Postoperatively Butorphanol (Turbugesic ${ }^{\circledR}$ ) analgesic and Flunixin anti-inflammatory were administered subcutaneously, both dose of $0.1 \mathrm{ml} /$ animal.

After 15 and 60 days of observation, the animals were euthanized by excessive injection of sodium pentobarbital anesthetic via intraperitoneal at a ratio of $100 \mathrm{mg} / \mathrm{kg}$. After being checked the animal's death an incision for careful dissection of the overlying soft tissue and the animals' femurs disarticulation was performed. These parts were removed and sent for histological study.
The segments intended for histology were fixed in $10 \%$ formalin, decalcified with Ethylene Diamino Tetra Acetate (EDTA) and processed for staining Hematoxylin and Eosin (HE).

The analysis of the behavior of the implanted material was performed using a qualitative-quantitative method for the analysis of the inflammatory infiltrate and the degradation of the material9, which the following classification was established: (0) absent; (1) $1 / 3$ of the completed field; (2) $2 / 3$ of the field and filled; (3) greater than $2 / 3$ of the completed field. Regarding the neoformed bone trabeculae around or inside the implant and the connective tissue around the implants only the presence or absence thereof were analyzed.

Thus, for each group, the mean and standard deviation of the intensity levels of inflammatory infiltrate were calculated based on an intensity scale ranging from 0 to 3 points. Then the means of the calculated points were also arranged in proportion to their presence in the microscopic field.

The difference hypothesis for Inflammatory Infiltrate and also for Material Degradation was tested between groups $A$, $B$ and $C$ at times 15 and 60 days. The values were compared between the groups by the ANOVA test Factor $a \times b$. The level of significance was determined as $\alpha=0.05$.

Osteoconduction was identified through histological study, the hypothesis of dependence between the presence and absence of neoformed trabeculae for the groups and periods studied was tested using the $G$ test and it was maintained the level of significance of $p \leq 0.05$.

The scanning electron microscopy (SEM) was performed to analyze and characterize the morphology and structure of intramedullary rods (pores distribution and surface roughness). 


\section{- Results}

The photomicrographs performed for analysis of histological lesions of decalcified bone tissue according to each group exhibited in the medullary canal: A15 group - presence of amorphous brown staining material with formation of connective tissue around it. It exhibits mild mononuclear inflammatory cell infiltration and absence of neoformed trabecular bone; A60 group - amorphous material, light brown with deposition of connective organized tissue enveloping. It is observed the absence of inflammatory infiltrate and neoformed trabecular bone; B15 group - presence of amorphous pale brown material with deposition of connective tissue around the same, isolating it. It exhibits mild inflammatory infiltrate and absence of neoformed trabecular bone; B60 group - presence of amorphous light brown color material surrounded by connective tissue. It is also possible to be observed the presence of mild inflammatory infiltrate and absence of neoformed trabeculae bone; C15 group presence of amorphous, light brown material with deposition of connective organized and vascularized tissue around the same. It also shows the presence of neoformed trabeculae bone inside the pores of the graft and moderate inflammatory infiltrate in the medullary canal; C60 group - presence of amorphous, light brown material surrounded by connective tissue. The absence of inflammatory infiltrate and neoformed trabecular bone (Figure 1).

The implant behavior was evaluated by observing the biocompatibility, osseointegration, osteoconductive and biodegradability characteristics.

Biocompatibility and osseointegration were evaluated by the formation of capsule of connective tissue around the implant and the presence of inflammatory infiltrate in the same area. In all groups, a connective tissue capsule was observed involving the implanted nail and mild to moderate inflammatory infiltrate, which decreased with time as time went by.

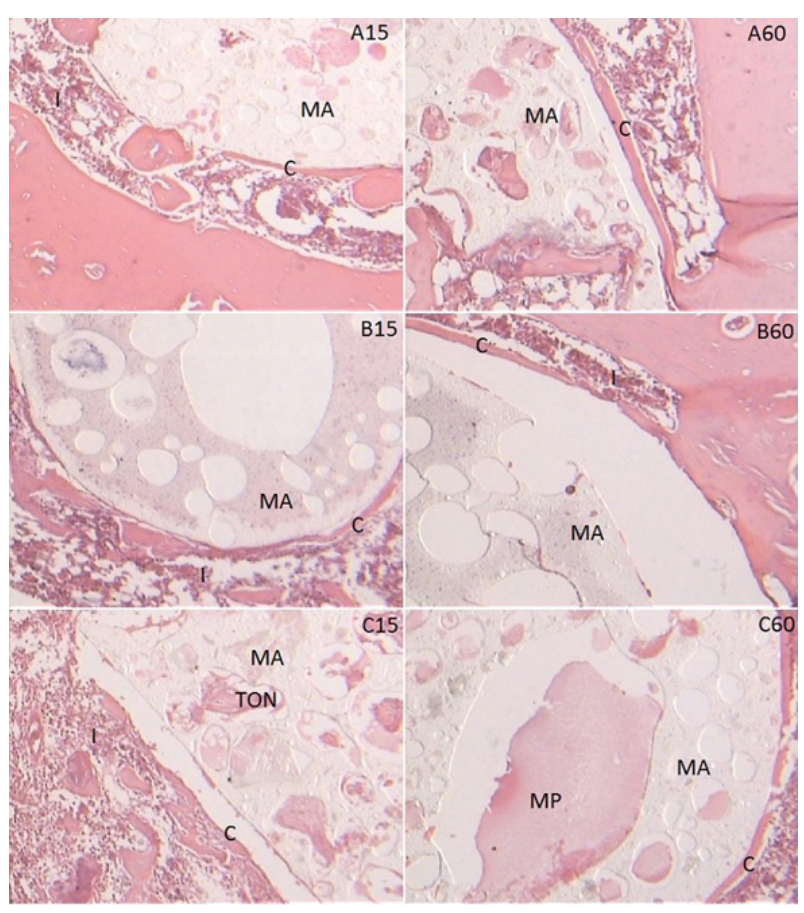

Figure 1 - Installation of histological lesions photomicrographs of bone tissue revealing: inflammatory infiltration (I), connective tissue capsule (C) amorphous material (MA) and newly formed trabeculae bone (TON) and protein material (MP). A15 refers to the group $A 15, A 60$ to the group $A 60, B 15$ to the group B15, B60 to the group B60, $\mathrm{C} 15$ to the group $\mathrm{C} 15$ and $\mathrm{C} 60$ to the group $\mathrm{C} 60$.

The biodegradability of the polymeric material performed in this study was measured by the reduction of this material at the implantation site.

The histological analysis results are shown in Tables 1 and 2.

The osteoconductive was identified by histological study, the dependence hypothesis between the presence and absence of newly formed trabecular bone to the groups and periods studied was tested using the $\mathrm{G}$ test and keeping the significance level of $p \leq 0.05$. 
Table 1 - Infiltration intensity for groups A, B and C at times 15 and 60 days. Intensity scale ranging from 0 to 3 points. Values expressed as sum of points for the 4 fields of view.

\begin{tabular}{lcccc}
\hline Days & GA & GB & GC & P value \\
\hline 15 days & 5 & 5 & 9 & 0.0733 \\
60 days & 1 & 3 & 2 & \\
\hline$P$ value & & 0.0002 & & \\
\hline
\end{tabular}

Table 2 - Material degradation for groups A, B and C at times 15 and 60 days. Intensity scale ranging from 0 to 3 points. Values expressed as sum of points for the 4 fields of view.

\begin{tabular}{lcccc}
\hline Days & GA & GB & GC & P value \\
15 days & 5 & 4 & 3 & 0.5459 \\
60 days & 9 & 5 & 6 & \\
\hline P value & & 0.1542 & & \\
\hline
\end{tabular}

The values show a significant dependence on the presence or absence of newly formed trabecular bone $(p=0.0288)$, indicating the presence trend only for the C15 group and did not present osteoconduction in the other groups (Table 3 ).

Table 3 - Frequency of distribution according to the absence or presence of newly formed trabecular bone for groups $\mathrm{A}, \mathrm{B}$ and $\mathrm{C}$ at times 15 and 60 days.

\begin{tabular}{|c|c|c|c|c|c|c|c|}
\hline & \multicolumn{6}{|c|}{ TON } & \multirow{2}{*}{ Tota } \\
\hline & A15 & B15 & C15 & A60 & B60 & C60 & \\
\hline Absence & 4 & 4 & 1 & 1 & 3 & 3 & 16 \\
\hline Presence & 1 & 0 & 4 & 4 & 1 & 2 & 12 \\
\hline Total & 5 & 4 & 5 & 5 & 4 & 5 & 28 \\
\hline$P$ value & & & 0.028 & & & & \\
\hline
\end{tabular}

In SEM photomicrographs were taken with magnification of 100 and 250 magnifications to characterize the morphology and structure of the castor bean polymer (pores and roughness distribution).

The photomicrographs of preimplanted castor bean polymer rods revealed morphological differences between different groups analyzed.
In group A which corresponds to castor bean doped polymer rods with bioactive glass it was observed moderate roughness and the presence of large quantities of varying sizes pores. The morphological structure of the castor bean polymer of the group B has little roughness and pores with diameters more regular and smaller compared to the previous group. But in the $\mathrm{C}$ group the surface is quite 
rough with presence of pores with smaller diameters and in large quantities when compared with group $\mathrm{A}$ and $\mathrm{B}$.

\section{- Discussion}

The biocompatibility of the castor bean polymer, that is, the acceptance of the organism concerning the implanted material without significant inflammatory focus signals and no foreign body granulomatous reaction was observed in this study in all groups and has been highlighted by several authors after implant in bone defects ${ }^{10,11}$.

In this research it was initially noticed the presence moderate to mild inflammatory infiltrate that decreased with time elapsed, but this difference was not statistically significant in Group B. The results also demonstrate the formation of connective tissue capsule around the implanted material in $100 \%$ of animals evaluated in all the periods studied, thus there was no decrease in the presence of connective tissue capsule as time goes by. In contrast, Celeste et $a .^{12}$, evaluated the tissue response to the implantation of polyurethane discs derived from castor bean oil in Wistar rats and observed that, initially, there was a moderate inflammatory reaction which decreased in intensity as the formation of fibrous connective tissue around the implants was intensified.

The combination of hydroxyapatite and bioactive glass to the castor bean polymer did not cause difference in results regarding biocompatibility and the presence of initial inflammatory infiltrate decreased over time compared to the group that only the castor bean polymer was implanted.

The inflammatory reaction found in this research is a natural feature in this regeneration phase10. The dense connective tissue found around the castor bean polymer in the early periods in all groups evaluated in this study should not be confused with that fibrous tissue responsible for isolating non biocompatible bodies. The main difference between these two is that the fibrous capsule is constituted by collagen fibers, while the dense connective tissue has in its composition both collagen fibers as a major cell population that may later differentiate into cells osteoprogenitress ${ }^{13,14}$.

Compared to the initial inflammatory reaction that occurred in this work, it is considered as a natural defense mechanism of the body, as observed by Hamerschmidt et al. ${ }^{15}$ who analyzed the hydroxyapatite action in bone regeneration in defects created in the mastoid rats and concluded that the hydroxyapatite was biocompatible without the formation of foreign body granuloma and presence of moderate inflammatory infiltrate, but it also occurred in the control group and it is therefore a normal reaction that occurs early in the bone tissue repair.

Whereas the osteoconduction, which is characterized as the ability to drive or direct the neobone formation over and between the structure of the filling material, was not observed in most groups and, in particular, in the group where the rod is formed only with polymer, fact which differs from results found in the literature ${ }^{16,17}$, for example, Nacer et al. ${ }^{14}$ that evaluating the biological behavior of the castor bean polymer containing silica nanoparticles, as a bone substitute, and observed that there was bone growth in all groups, also diverging from the results of Costa et al. ${ }^{18}$ who concluded that hydroxyapatite, tricalcium phosphate- $\beta$ and HA / TCP- $\beta$ association exhibit excellent bone repair capacity and can be used as bone substitutes.

The porosity of the material favors the osteoconduction because it allows the tissue growth inside of ${ }^{19}$. The size and pore interconnectivity at the surfaces of biomaterials have a crucial influence on bone formation ${ }^{20}$.

As also suggested by the results of Nacer et $a .^{21}$, the adhesion and growth of bone tissue depends on the surface regularity. Fibroblasts seem to avoid the rough surfaces and accumulate in smoother regions. In contrast, macrophages, epithelial and osteoblastic cells adhere more easily to rough surfaces. 
Despite the importance of porosity and roughness of the implanted material, the structural features found in the manufactures rods did not favor the osteoconductive implant process in the spinal canal.

In the case of biodegradability, after 60 days of biomaterials implantation, it was observed slight degradation or absorption of grafted material, in all groups, but this degradation was not statistically significant when compared to the initial evaluation period that was 15 days. These results corroborate the findings of Laureano Filho et al. ${ }^{10}$ who concluded that the castor bean polymer was little reabsorbed after 15 weeks of research comparing the action of demineralized bone from human origin and the castor bean polymer on bone healing in cavities made in 24 rabbits calvarial. As Pereira et al. ${ }^{22}$ evaluated through radiographic and histological examinations, the function of the castor bean polymer in bone defects performed in the shaft of rabbits radios and verified at 15, 30, 60 and 120 days of postoperative that the polymer castor bean acted as filler space, minimizing the production of fibrous tissue at the site and showed no signs of resorption in any of the evaluation times.

The association of hydroxyapatite and bioactive glass in the graft did not influence statistically the degradation of the implant, similar to the result obtained by Duarte et al. ${ }^{23}$ that after 60 days of filling with hydroxyapatite in vestibular surface, maintained a constant volume with bone formation and intense neovascularization. However, in relation to bioactive glass, Tiomis et al. ${ }^{24}$ did not notice their presence even after the same evaluation period, suggesting complete absorption.

Finally, the ideal implant for fixing to lose its strength gradually, transferring the mechanical stress that is inherent to the fracture site being reabsorbed by the organism when this is not necessary, not being necessary a new surgery to remove $i^{3}$. In the case of polymer rods implantation in the medullary canal, as in this experiment, the ideal is that this absorption is slow and gradual, so it can be effective in securing and stabilizing more extensive fractures that require a longer time to repair.

\section{Conclusion}

Castor bean polymer associated with bioactive glass and hydroxyapatite in the medullary canal was biocompatible and osseointegrated when considered that there was not an intense inflammatory reaction nor fibrous tissue capsule formation isolating the implant. Castor bean polymer proved to be osteoconductive materials only in the $\mathrm{C} 15$ Group, i.e. in the early periods of the presence of hydroxyapatite and bioactive glass. And, the biodegradability of the polymeric material, even when associated with bioactive glass and hydroxyapatite, was not observed in this study, because the presence of this material in the medullary canal was constant in all groups.

\section{References}

1. Spadeto Junior O, Faleiros RR, Alves GES, Casas EBL, Rodrigues LB, Loiacono BZ, Cassou F. Failures in the use of polyacetal and polyamide in the form of intramedullary interlocking nail for immobilization of induced femoral fracture in young cattle. Cienc Rural. 2010 Abr;41(4):907-12. doi: $10.1590 / \mathrm{S} 010384782010005000038$.

2. Sapadeto Junior O, Rodrigues LB, Carvalho WTV, Moreira DO, Marval CA, Costa CG, Alves GES, Las Casas EB, Faleiros RR. . Sistema osso-implante ex vivo utilizando haste intramedular polimérica para imobilização de fraturas femorais em bovinos jovens. Cienc Rural. 2011 Fev;41(2):301-6. doi: 10.1590/S0103-84782011000200020.

3. Ferreira BMP, Steffen AM, Cardoso TP, Alberto-Rincon MC, Duek, EAR. Haste intramedular polimérica bioreabsorvível (PLLA/PHBV) para uso na recuperação de fraturas ósseas. Polímeros. 2008;18(4):312-9. doi: 10.1590/S010414282008000400010.

4. Rodrigues LB. Aplicações de biomateriais 
em ortopedia. Estudos Tecnol Eng. 2003 Jul/Dez;9(2):63-76. doi: 10.4013/ ete.2013.92.02.

5. Derceli JR, Fais LMG, Pinelli LAP. A castor oil-containing dental luting agente: effects of cyclic loading and storagetime on flexural strength. J Appl Oral Sci. 2014 Ago;22(6):496501. doi: 10.1590/1678-775720140069.

6. Camargo AFF, Baptista AM, Natalino R, Camargo OP. Vidro Bioativo em defeitos cavitários: estudo experimental comparativo em coelho. Acta Ortop Bras. 2015;23(4):2027. doi: $10.1590 / 1413785220152304147538$.

7. Bonan RF, Bonan PRF, Batista AUD, Oliveira JE, Menezes RR, Medeiros ES. Methods os microstructural Strengthening of hydroxyapatite. Ceramica. 2014 Jul/Set;60(355):402-10. doi: 101590/5036669132014000300012.

8. Reis ECC, Borges APB, Oliveira PM, Bicalho SMCM, Reis AM, Silva $\mathrm{Cl}$. Desenvolvimento e caracterização de membranas rígidas, osteocondutoras e reabsorvíveis de polihidroxibutirato e hidroxiapatita para regeneração periodontal. Polímeros. 2012;22(1):73-79. doi: 10.1590S010414282012005000007.

9. Silva SI, Aydos RD, Faloppa F, Gomes PO. Estudo morfológico da regeneração óssea em coelhos submetidos a complementação de cálcio na alimentação. Acta Cir Bras. 2000;15(1):44. doi: 10.1590/S010286502000000500036 .

10. Laureano Filho JR, Branco BLC, Andrade ESS, Barbosa JRA. Comparação histológica entre o osso desmineralizado e polímero de mamona sobre a regeneração óssea. Rev Bras Otorrinolaringol. 2007 Mar/ Abr;73(2):186-92. doi: 10.1590/S003472992007000200008.

11. Mendonça JCG, Rossi R, Inouye CM, Bazan DRP, Monteiro JCC, Mendonça JP. Morphology of autogenous bone graft and castor oil polyurethane in the infraorbital rim of rabbits: a comparative study. Acta Cir Bras. 2006 Sep/Oct;21(5):341-7. doi: 10.1590/S0102-86502006000500012

12. Celeste AS, Rahal SC, Pereira-Junior COM, Sequeira JL, Melo SM. Resposta tecidual a implantes de discos de poliuretana de mamona nas formas pré-moldada ou biomassa moldada. Pesqui Vet Bras. 2010 Dez;30(12):1089-95. doi: 10.1590/S0100736X2010001200015.

13. Leonel ECF, Porciúncula HF, Andrade Sobrinho J, Ramalho LTO, Mangilli PD, Rapoport A. A ação do polímero de mamona durante a neoformação óssea. Acta Cir Bras. 2004 Ago;19(4):342-50. doi: 10.1590/ S0102-86502004000400005.

14. Nacer RS, Poppi RR, Carvalho PTC, Silva BAK, Odashiro NA, Silva IS, Delben JRJ, Delben AAST. Castor oil polyurethane containing silica nanoparticles as filling material of bone defect in rats. Acta Cir Bras. 2012 Jan;27(1):56-62. doi: 10.1590/ S0102-86502012000100010.

15. Hamerschmidt R, Santos RF, Araújo JC, Stahlke Junior HJ, Agulham MA, Moreira AT, Mocellin M. Hidroxyapatite granules used in the obliteration of mastoid cavities in rats. Braz J Otorhinolaryngol. 2011 May/ Jun;77(3):315-21. PMID: 21739005.

16. Valente FL, Reis ECC, Sepúlveda RV, Ochoa CCR, Santos LC, Corsini CM, Borges APB. Hydroxyapatite, polycaprolactone and alendronate composites for bone regeneration in rabbits' olecranon: histological features. Arq Bras Med Vet Zootec. 2016 Mar/Apr;68(2):543-7. doi: 10.1590/1678-4162-8343.

17.Valente FL, Santos LC, Sepúlveda RV, Gonçalves GP, Eleotério RB, Reis ECC, Borges APB. Hydroxyapatite-lignin composite as a metallic implant-bone tissue osseointegration improver: experimental study in dogs. Cienc Rural. 2016 Fev;46(2):324-9. doi: 101590/01038478 cr20150110.

18. Costa BD, Camargo NH, Oleskovicz N, Gava A, Dallabrida AL, Regalin D, Lima MPA, Moraes AN. Neoformação óssea e osteointegração de biomateriais micro e nanoestruturados em ovinos. Pesq Vet Bras. 2015 Fev;35(2):177-87. doi: 10.1590/ S0100-736X2015000200015.

19. Dias PCJ, Granato L, Ramalho LT, Oliveira $J A$, Pretel H. Avaliação histológica da 
biocompatibilidade do polímero de mamona no dorso nasal de macacos-pregos (Cebus apella). Braz J Otorhinolaryngol. 2009 Mai/Jun;75(3):350-5. doi: 10.1590/ S1808-86942009000300007.

20. Aparecida AH, Guastaldi AC, Fook MVL. Desenvolvimento e caracterização de suportes porosos de polietileno de ultra alto peso molecular (PEUAPM) para utilização como biomaterial para reposição e regeneração óssea. Polímeros. 2008;8(4):277-80. doi: 10.1590/S010414282008000400004.

21. Nacer RS, Silva BAK, Poppi RR, Silva DKM, Cardoso VS, Delben JRJ, Delben AAST. Biocompatibility and osteogenesis of the castor bean polymer doped with silica (SiO2) or barium titanate (BaTiO3) nanoparticles. Acta Cir Bras. 2015 Apr;30(4):255-63. doi: 10.1590/S0102-865020150040000004.

22. Pereira Junior COM, Rahal SC, Yamaguti
P, Felisbino SL, Pavan PT, Vulcano LC. Comparison between polyurethanes containing castor oil (soft segment) and cancellous bone autograft in the treatment of segmental bone defect induced in rabbits. J Biomater Appl. 2007;21:283-97. PMID: 16543284.

23. Duarte TS, Borges APB, Lavor MSL, Filgueiras R, Tsiomis AC, Oliveira FL, Pontes KCS. Osteointegração da hidroxiapatita sintética no processo alveolar da mandíbula de cães: aspectos histológicos. Arq Bras Med Vet Zootec. 2006;58(5):849-53. doi: 10.1590/S0102-09352007000100019.

24. Tiomis AC, Borges APB, Daibert APF, Duarte TS, Pontes KCS, Carvalho TB, Carlo Reis EC. Avaliação histológica do biovidro particulado na reparação de defeito experimental em mandíbula de cães. Arq Bras Med Vet Zootec. 2010;62(1):80-5. doi: $10.1590 / \mathrm{S} 0102-09352010000100011$.

\section{Correspondence:}

Viviani Teixeira dos Santos

Rua Norberto Ribeiro de Souza, 347

79042-452 Campo Grande - MS Brasil

Tel.: (55 67)9255-7377

vivianitsantos@gmail.com

Conflict of interest: none

Financial source: FUNDECT
Received: Oct 19, 2016

Review: Dec 16, 2016

Accepted: Jan 20, 2017

${ }^{1}$ Research performed at Postgraduate Program in Health and Development, West Central Region, Universidade Federal do Mato Grosso do Sul (UFMS), Campo Grande-MS. Brazil. Part of Master degree thesis, Postgraduate Program in Health and Development. Tutor: landara Schettert da Silva. 